\title{
Effect of the Extensive Use of Granites as Countertops in Luxury Buildings on the Indoor Radon Concentration and the Potential Risk to Occupants
}

\author{
Mohammed S. Tayeb', MSc, and Abdulraheem A. Kinsara, PhD
}

Department of Nuclear Engineering, Faculty of Engineering and ${ }^{1}$ Center of Training and Radiation

Protection, King Abdulaziz University, Jeddah, Saudi Arabia

\section{Correspondence}

Mr. Mohammed S. Tayeb

P.O. Box 80204, Jeddah 21589, Saudi Arabia

e.M: mtaybe@kau.edu.sa

\section{Submission: 21 Jun. 2015 \\ Accepted: 6 Sep. 2015}

\section{Citation}

Tayeb MS, Kinsara AA. Effect of the extensive use of granites as countertops in luxury buildings on the indoor radon concentration and the potential risk to occupants. JKAU Med Sci 20xx; 22 (4): 9-17. DOl: 10.4197/Med. 22.4.2

\begin{abstract}
Radon concentration has been measured inside the new buildings of King Abdulaziz University to study the effect of the extensive use of granites as countertops on the indoor radon concentration. A set of indoor and outdoor measurements has been conducted using radon measurement instruments. For comparison, indoor radon concentration was also measured in the older buildings, where granite countertops were in use at only a few sites near the main entrances. The obtained results indicate that the average indoor radon concentrations were $8.8 \pm 4.8$ and $11.2 \pm 4.9 \mathrm{~Bq} / \mathrm{m}^{3}$ in the old and new buildings, respectively. The average outdoor concentration was about $4.4 \mathrm{~Bq} / \mathrm{m}^{3}$. These values are lower than the global average values. The average annual effective dose due to indoor radon was calculated for the general public and for the occupants of the new buildings. Risk estimates have been done based on the average radon concentration values. The average annual effective dose for the public due to radon inhalation was estimated to be $0.264 \mathrm{mSv}$, and for the occupants of the new buildings to be $0.280 \mathrm{mSv}$. The associated risk of lung cancer mortality to inhabitants due to lifetime radon inhalation is estimated to be $102.9 \times 10^{-5}$ for the public and $109.5 \times 10^{-5}$ for the occupants of the new buildings.
\end{abstract}

\section{Keywords}

Radon-222, Granite, Exposure dose rate, Radiation risk, Radiation measurement, Dosimetry

\section{Introduction}

Granites are primary igneous rocks formed by the Earth's geological processes during the slow cooling age. They contain varying concentrations of uranium and thorium which are the primary sources of the $\gamma$-emitting radionuclides, including radon ( $\left.{ }^{222} \mathrm{Rn}\right)$ gas, a source of alpha and beta particles and gamma rays ${ }^{[1-}$ 5]. Granites are quarried and processed to produce commercial products such as countertops, widely used in building construction, due to their durability and decorative appearance. Although this advantage makes granite a popular building material it may cause an increase in radiation dosage to occupants. 
It is likely that granite countertops used in luxury buildings could variably increase the radiation dose above the normal natural background dose that comes from soil and other building materials, resulting in potential risk to consumers. For buildings constructed on normal soils, both the subsoil and its released radon gas generate radiation dose for occupants ${ }^{[6]}$. Assessments using indoor measurements indicated that some granite slabs could increase the indoor radon concentration by about $40 \mathrm{~Bq} / \mathrm{m}^{3}(1 \mathrm{pCi} / \mathrm{L})$, with higher concentrations for more elevated slabs ${ }^{[7]}$.

Radon and its progenies in air are the main contributors to the radiation dose of the public. On considering the global average total effective dose (2.4 $\mathrm{mSv}$ ) to the public, about $60 \%$ of this dose is related to radon exposure via inhalation ${ }^{[8]}$. Epidemiological studies show a clear link between exposure to radon in air and lung cancer ${ }^{[9]}$, where the lifetime risk of lung cancer mortality from radon exposure of $150 \mathrm{~Bq} / \mathrm{m}^{3}$ in air is about $2.3 \%$.

The United States Environmental Protection Agency (USEPA) has established an action level of 148 $\mathrm{Bq} / \mathrm{m}^{3}$ for radon in residential indoor air ${ }^{[10]}$. Similarly, the International Commission on Radiological Protection (ICRP) recommends an action level for radon in indoor air of dwellings that is higher than 200 $\mathrm{Bq} / \mathrm{m}^{3}(5.4 \mathrm{pCi} / \mathrm{L})^{[11]}$

Granite countertops from local sources used for decoration in the new buildings of King Abdulaziz University (KAU), may result in increased dose to occupants. The granite is used in both office rooms and in most corridors, where the floors and wall-parts are decorated with granite countertops. At corridor intersections, the entire walls are decorated with granite slabs. However, evaluating the actual radiation dose to occupants of the new buildings is an objective.

The aim of this article is to address the question posed by the occupants as to whether the granite countertops significantly increase exposure dose rate to occupants of the new buildings due to radon gas emanating from the granite slabs into the indoor air. The present study was designed to answer this enquiry by providing the appropriate radiological data.

The following protocol was designed to achieve the aim of this study:

a). Measuring the activity concentration of radon in the indoor air of the old and new buildings of KAU. b). Measuring the activity concentration of radon in the outdoor atmosphere of KAU campus.

c). Estimating the radiation dose rate and annual effective dose to occupants due to radon inhalation, based on the obtained results.

d). Assessing the potential risk due to radon inhalation (usually risk of lung cancer mortality due to radon inhalation).

e). Comparing the estimates of doses to healthbased values for radiation safety published by authoritative organizations concerned with the protection of public health, such as the ICRP, the World Health Organization (WHO) and USEPA.

\section{Materials and Methods}

\section{Equipment}

Radon measurement instrument (RAD7) (DURRIDGE Company, Inc., Billerica, MA, USA), is an advanced, portable and easy to use radon measurement system. It contains an internal solid-state alpha detector. The instrument can be used in different modes, using the relevant accessories, for different applications such as measuring radon gas concentration in air, water and soil.

For quality control purposes of radon gas measurements in the atmosphere, the RAD7 instrument is sent periodically to the factory for calibration as instructed by the manufacturer.

\section{Radon Measurements in Air (Indoor and Out- door)}

The activity concentration of radon was measured in air by following the standard operating procedure of the instrument manual (www.durridge.com). Briefly, the instrument was connected to the appropriate accessories (inlet air filter, drying station, dry-stick and a printer), and fixed at the site of interest at $1 \mathrm{~m}$ above the floor and at equal distance from the sidewalls. The RAD7 instrument is controlled through the CAPTURE software and a four-key menu driven interface. The four keys allow to look at the commands and operate the instrument to collect the required data. Owing to the diurnal variation of radon releases, the measurement period was 24 hours. After the counting period, the result of radon activity concentration is automatically 
printed in a unit of $\mathrm{Bq} / \mathrm{m}^{3}$ of air, with the statistical error in $2 \sigma$ level. The new buildings were fully closed, while the air exchange systems and ventilation fans were running 24 hours. Radon concentration of the outside air was measured as inside the buildings except that the instrument was fixed at a site protected from both fast winds and direct sunlight.

A set of indoor and outdoor measurements for radon concentration were obtained covering various sites distributed throughout the buildings to be representative of the study area. The reported indoor radon concentration values are based on equilibrium with air change rate inside the buildings. The likely sources for the measured indoor radon concentrations are,

a) Radon emanation from granite countertops.

b) Radon contribution from other sources in the building materials.

c) Radon emanation from the subsoil in the ground floor.

d) Radon from the outer atmosphere due to air change.

The measured outdoor radon emanates from outer soil and is diluted by wind action. The difference between radon concentration in the new and old buildings is attributed to the use of granite countertops.

\section{Dose Due to Radon}

To calculate the annual effective dose, $\mathrm{H}_{\mathrm{E}^{\prime}}$ due to radon inhalation inside the buildings, which corresponds to the value of the radon concentration, the following equation ${ }^{[8]}$ was used:

$H_{E}=C_{R n} \times E q \times T \times 9 n S v\left(B q h / m^{3}\right)$

Where

$\mathrm{C}_{\mathrm{Rn}}=$ the radon concentration, in $\mathrm{Bq} / \mathrm{m}^{3}$.

$\mathrm{Eq}=$ the indoor equilibrium factor between radon and radon progenies (equals 0.4 in closed spaces, but under the air change equilibrium condition, this factor may be less and is difficult to estimate, therefore 0.4 was considered the maximum value).

$\mathrm{T}=$ the annual exposure time to this concentration in hours. Following UNSCEAR Report ${ }^{[11]}$, the annual indoor occupancy time fraction is 0.8 (7008 h/y) and the occupancy office time, where the occupants are exposed to extra dose due to granite countertops is assumed to be equal to 8 hours/day and 22 working days/ month and 10.5 months/year; this means 1848 $\mathrm{h} / \mathrm{y}$. The recommended dose conversion factor is the value $9 \mathrm{nSv}\left(\mathrm{Bq} \mathrm{h} / \mathrm{m}^{3}\right)$.

Using this equation, inhalation of $1 \mathrm{~Bq} / \mathrm{m}^{3}$ of indoor radon causes an effective dose of about $25.23 \mu \mathrm{Sv}$, and the annual effective dose due to inhalation of an extra $1 \mathrm{~Bq} / \mathrm{m}^{3}$ of indoor radon during office time causes an extra effective dose of about $6.65 \mu \mathrm{Sv}$. The extra dose relates to the difference in average radon concentration between traditional buildings (old buildings) and the new buildings with extensive use of granite countertops for decoration.

The above equation is also used to calculate the annual effective dose due to the inhalation of outside air radon. The annual exposure time fraction to this concentration is assumed to be $0.2(1752 \mathrm{~h} / \mathrm{y})$ and the value 0.6 is the equilibrium factor ${ }^{[8]}$. Based on these assumptions, inhalation of $1 \mathrm{~Bq} / \mathrm{m}^{3}$ of outdoor radon causes an effective dose of about $9.46 \mu \mathrm{Sv}$.

\section{Lung Cancer Risk Due to Radon Inhalation}

Following $B E I R V{ }^{[12]}$ report, a risk of lung cancer mortality due to lifetime exposure to air-radon at an activity level of $1 \mathrm{~Bq} / \mathrm{m}^{3}$ was estimated. This value is based on risk projections predicted from previous studies of several workers. Accordingly, a risk projection of $1.3 \times 10^{-4}$ per unit concentration in air $\left(1 \mathrm{~Bq} / \mathrm{m}^{3}\right)$ was developed. The value was for a mixed population of smokers and nonsmokers. However, the value $1.3 \times 10^{-4}$ is used in this work for nonsmokers, to estimate the excess risk of lung cancer mortality that could be attributed to radon gas inhalation, considering the lifetime inhalation of a certain average concentration and the occupancy time fraction of each concentration.

\section{Results}

\section{Radon Measurements in Air}

The data in Table 1 show that the activity concentration of radon inside the new buildings, where granite countertops are extensively used for decoration of entrances, corridors and some office rooms, varyied within a narrow range (7.8 to $\left.20.7 \mathrm{~Bq} / \mathrm{m}^{3}\right)$, with an average value of $11.2 \pm 4.9 \mathrm{~Bq} / \mathrm{m}^{3}$. The outdoor radon concentration was much lower (less than $5.4 \mathrm{~Bq} / \mathrm{m}^{3}$ ). Table 2 shows the radon measurement results inside 
the old buildings. The activity concentration of indoor radon inside the old buildings also varied in a narrow range $\left(6.3\right.$ to $\left.13.8 \mathrm{~Bq} / \mathrm{m}^{3}\right)$, with an average value of about $8.8 \pm 4.8 \mathrm{~Bq} / \mathrm{m}^{3}$. The obtained results of Tables 1 and 2 are summarized in Table 3. Table 4 shows a summary of the present indoor radon concentration values together with some examples of other international values.

\section{Effective Dose Rate and Risk Due to Radon}

The obtained average radon concentration is used to calculate the average effective dose rate (Table 5). In addition, the probability of lung cancer mortality due to lifetime exposure to radon is estimated and presented in Table 5. Generally, the estimation of lung cancer mortality due to exposure to radon has a large number

Table 1. Indoor and outdoor radon levels of the new building.

\begin{tabular}{|c|c|c|c|c|}
\hline \multirow{2}{*}{ Site } & \multicolumn{2}{|c|}{ Specifications } & \multirow{2}{*}{ Level } & \multirow{2}{*}{${ }^{222} \mathrm{Rn}$ concentration, $\mathrm{Bq} / \mathrm{m}$} \\
\hline & Floor & Walls & & \\
\hline \multirow{10}{*}{ Main Corridor } & \multirow{10}{*}{ Red and white granite } & \multirow{10}{*}{$1.25 \mathrm{~m}$ height of red granite } & \multirow{2}{*}{$0^{*}$} & $8.4 \pm 3.0$ \\
\hline & & & & $11.8 \pm 4.9$ \\
\hline & & & \multirow{2}{*}{1} & $9.9 \pm 3.5$ \\
\hline & & & & $10.2 \pm 3.5$ \\
\hline & & & \multirow[b]{2}{*}{2} & $9.2 \pm 3.4$ \\
\hline & & & & $11.1 \pm 4.1$ \\
\hline & & & \multirow{2}{*}{3} & $10.4 \pm 3.3$ \\
\hline & & & & $12.6 \pm 4.6$ \\
\hline & & & \multirow{2}{*}{4} & $12.6 \pm 4.2$ \\
\hline & & & & $10.7 \pm 3.5$ \\
\hline \multirow{14}{*}{ Corridors } & \multirow{10}{*}{ Red and white granite } & \multirow{10}{*}{$1.25 \mathrm{~m}$ height of red granite } & \multirow{2}{*}{0} & $9.5 \pm 3.3$ \\
\hline & & & & $10.6 \pm 4.6$ \\
\hline & & & \multirow{2}{*}{1} & $16.3 \pm 5.4^{* *}$ \\
\hline & & & & $11.6 \pm 5.1$ \\
\hline & & & \multirow{2}{*}{2} & $12.3 \pm 3.3$ \\
\hline & & & & $10.3 \pm 3.7$ \\
\hline & & & \multirow{2}{*}{3} & $9.2 \pm 3.3$ \\
\hline & & & & $10.5 \pm 3.3$ \\
\hline & & & \multirow{2}{*}{4} & $15.8 \pm 3.9^{* *}$ \\
\hline & & & & $11.2 \pm 3.3$ \\
\hline & \multirow{4}{*}{ Pottery tiles } & \multirow{4}{*}{$1.25 \mathrm{~m}$ height pottery tiles } & \multirow{4}{*}{0} & $11.2 \pm 5.3$ \\
\hline & & & & $10.2 \pm 4.1$ \\
\hline & & & & $11.8 \pm 4.2$ \\
\hline & & & & $8.2 \pm 4.6$ \\
\hline \multirow{12}{*}{ Offices } & Concrete & Concrete & 0 & $8.3 \pm 3.4$ \\
\hline & Pottery tiles & & 0 & $11.2 \pm 2.4$ \\
\hline & White aranite & & & $20.7 \pm 4.9^{* *}$ \\
\hline & White granite & Concrete & 1 & $11.3 \pm 5.0$ \\
\hline & Red and white granite & & & $8.2 \pm 1.8$ \\
\hline & Rea ana wnite granite & Concrete & 2 & $9.9 \pm 2.7$ \\
\hline & White granite & & & $13.9 \pm 5.2^{* *}$ \\
\hline & Bed and white aranite & & & $11.5 \pm 3.7$ \\
\hline & kea ana wnite granite & Concrete & 3 & $10.6 \pm 3.4$ \\
\hline & White granite & & & $7.8 \pm 3.3$ \\
\hline & & & & $14.9 \pm 4.8^{* *}$ \\
\hline & White granite & Concrete & 4 & $10.4 \pm 3.7$ \\
\hline & & & & $13.9 \pm 5.1$ \\
\hline Wide Yard & Red ana wnite granite & Rea granite & 1 & $9.7 \pm 2.0$ \\
\hline & & & & $9.1 \pm 4.4$ \\
\hline Car Park & Concrete & Concrete & 0 & $9.6 \pm 2.1$ \\
\hline & & & & $5.4 \pm 2.7$ \\
\hline Open Air & Concrete & Open area & 0 & $3.8 \pm 2.5$ \\
\hline & & & & $4.1 \pm 2.4$ \\
\hline
\end{tabular}

"O level = ground level; " Closed places of slow air change Abbr: ${ }^{222}$ Rn: Radon 
Effect of the Extensive Use of Granites as Countertops in Luxury Buildings...

Table 2. Radon levels inside the old building.

\begin{tabular}{|c|c|c|c|c|}
\hline \multirow{2}{*}{ Site } & \multicolumn{2}{|c|}{ Specifications } & \multirow{2}{*}{ Level } & \multirow{2}{*}{${ }^{222} \mathrm{Rn}$ Concentration, $\mathrm{Bq} / \mathrm{m}^{3}$} \\
\hline & Floor & Walls & & \\
\hline \multirow{2}{*}{ Entrance } & \multirow{2}{*}{ Brown granite } & \multirow{2}{*}{ Concrete } & \multirow{2}{*}{0 (Ground Floor) } & $10.4 \pm 4.3$ \\
\hline & & & & $11.8 \pm 4.9$ \\
\hline \multirow{6}{*}{ Corridors } & \multirow{6}{*}{ Marble } & \multirow{6}{*}{ Concrete } & \multirow{3}{*}{0} & $7.4 \pm 4.5$ \\
\hline & & & & $8.2 \pm 4.2$ \\
\hline & & & & $7.9 \pm 4.3$ \\
\hline & & & \multirow{3}{*}{1} & $6.3 \pm 2.2$ \\
\hline & & & & $7.1 \pm 4.2$ \\
\hline & & & & $7.4 \pm 4.2$ \\
\hline \multirow{6}{*}{ Offices } & \multirow{6}{*}{ Concrete } & \multirow{6}{*}{ Concrete } & \multirow{3}{*}{0} & $9.8 \pm 4.3$ \\
\hline & & & & $13.8 \pm .6 .8$ \\
\hline & & & & $9.5 \pm 4.1$ \\
\hline & & & \multirow{3}{*}{1} & $8.4 \pm 3.3$ \\
\hline & & & & $7.2 \pm 4.4$ \\
\hline & & & & $7.9 \pm 4.0$ \\
\hline
\end{tabular}

Abbr: ${ }^{222}$ Rn: Radon

Table 3. Comparison between the indoor radon concentration in new and old buildings.

\begin{tabular}{|c|c|c|c|c|c|}
\hline \multirow{2}{*}{ Site } & \multicolumn{4}{|c|}{ Radon Concentration, $\mathbf{B q} / \mathbf{m}^{3}$} & \multirow{2}{*}{ Percent Increase } \\
\cline { 2 - 6 } & \multicolumn{2}{|c|}{ New Building Building } & \\
\cline { 2 - 6 } & Average & Range & Average & Range & \\
\hline Indoor & $11.2 \pm 4.9$ & $7.8-20.7$ & $8.8 \pm 4.8$ & $6.3-13.8$ & 27.3 \\
\hline Outdoor & $4.4 \pm 2.8$ & $3.8-5.4$ & $4.4 \pm 2.8$ & $3.8-5.4$ & 00.0 \\
\hline
\end{tabular}

Table 4. Comparison between the present indoor radon concentration values and some other international values.

\begin{tabular}{|c|c|c|c|}
\hline \multirow{2}{*}{ Country } & \multicolumn{2}{|c|}{ Rn Concentration, Bq/ $\mathbf{m}^{3}$} & \multirow{2}{*}{ Reference } \\
\cline { 2 - 3 } & Average & Range & The present study \\
\hline Saudi Arabia & 11.2 & $7.8-20.7$ & {$[22]$} \\
\hline Saudi Arabia & 54.6 & $12.0-125.6$ & {$[16]$} \\
\hline Brazil & 61 & $12-920$ & {$[21]$} \\
\hline Egypt & 43 & $9.9-76.1$ & {$[19]$} \\
\hline Vietnam & 10 & $4.0-27$ & {$[20]$} \\
\hline Cyprus & 11 & $2-134$ & {$[23]$} \\
\hline Sweden & -- & $100-5000$ & {$[24]$} \\
\hline Palestine & 117 & $26-611$ & \\
\hline
\end{tabular}

Table 5. The average effective dose rate and the estimated risk of lung cancer mortality due to radon inhalation.

\begin{tabular}{|c|c|c|c|}
\hline & Average Radon Concentration, $\mathbf{B q} / \mathbf{m}^{3}$ & Annual Effective Dose, $\mathbf{m S v}$ & Risk \\
\hline Outdoor & 4.4 & 0.042 & $11.4 \times 10^{-5}$ \\
\hline Indoor & 8.8 & 0.222 & $91.5 \times 10^{-5}$ \\
\hline Extra Dose & 2.4 & 0.016 & $6.6 \times 10^{-5}$ \\
\hline
\end{tabular}


of unavoidable uncertainties due to uncertainties in parameter estimates such as the averages used for occupancy factors, radon/radon daughters' equilibrium factors and radon concentration.

\section{Discussion}

No explicit difference was found in radon concentration between sites of the same characteristics in the different levels, including the ground level (Table 1). For example, the main corridors of the different levels have undistinguishable differences in indoor radon concentration. This is the case with any of the other sites (corridors, offices or laboratories). The radon concentration in the atmosphere of the ground levels was almost the same as that of the other levels indicating that the effect of subsoil source of radon is insignificant. The narrow range of variation in indoor radon concentration may be related to its migration inside the buildings, and is assumed to be in equilibrium with the air change rate. Lower air-change rate sites, such as closed rooms, stair-rooms and closed terminals of corridors, showed significantly higher values due to local radon accumulation (Table 1). Usually, lower radon concentrations with little variation is reported for outdoor radon levels due to the dilution by the wind action.

The data in Table 3 indicates that about a 27.3\% increase in average indoor radon concentration of the new buildings attributable to the granite countertops. Variations in indoor radon concentration have been reported by many workers ${ }^{[13-16]}$. The average indoor radon concentration is still significantly lower than the global average concentration of $40 \mathrm{~Bq} / \mathrm{m}^{3[17]}$, despite the extensive use of granite. In addition, the radon concentrations in all buildings were found to be far below the USEPA recommended action level of $148 \mathrm{~Bq} / \mathrm{m}^{3[18]}$ and no samples exceeded or were close to the action limit of $74 \mathrm{~Bq} / \mathrm{m}^{3}$. This may be related to the measurement conditions. The global average value is based on the standard measurement conditions (measurement inside closed chambers), whereas measurements in this study were conducted under continuous air change condition inside the buildings (the typical conditions under which the occupants spend their business time). The present data is comparable with data of other workers ${ }^{[19,20]}$. The outdoor radon levels (3.8 to $5.4 \mathrm{~Bq} / \mathrm{m}^{3}$ ) were below the limit value of global average of $10 \mathrm{~Bq} / \mathrm{m}^{3[8]}$. The average indoor radon level was about 2.5 times higher than that of the outdoors. Sarrou and Pashalidis ${ }^{[20]}$ reported a factor of $1.5 \mathrm{in} \mathrm{low} \mathrm{level} \mathrm{data,} \mathrm{and} \mathrm{a} \mathrm{factor} \mathrm{of}$
5 by other workers ${ }^{[16,21]}$ in higher level data, indicating the effect of radon emanation and radon change rates on this factor.

The location of Jeddah City at the Eastern Red Sea Coast may has some contribution to lowering the outdoor radon levels due to the radon-depleted air coming from the sea. This factor, together with the indoor measurement condition (indoor air change) contributed to lowering the indoor radon concentration. Another local study ${ }^{[22]}$ indicated an average indoor radon concentration of $54.6 \mathrm{~Bq} / \mathrm{m}^{3}$. This higher value relates to different factors such as the measurement conditions, where the measurements were carried out in closed chambers (no air change) of town homes located in a high natural background radiation area away from the sea. The average outdoor radon concentration in the latter area was $10.3 \mathrm{~Bq} /$ $\mathrm{m}^{3}$, which is consistent with the global average value. The reported average radon levels inside dwellings in Pocos de Caldas, Brazil was $61 \mathrm{~Bq} / \mathrm{m}^{3[16]}$, which is much higher than the present data due to the higher background radiation of that plateau, but very low compared to indoor radon values reported by other workers ${ }^{[23]}$, ranging from 100 to $5000 \mathrm{~Bq} / \mathrm{m}^{3}$. The WHO recommended a reference limit value of $100 \mathrm{~Bq} / \mathrm{m}^{3}$ for indoor radon, otherwise remediation projects should be planned. Such projects may include aeration and/ or development of building codes requiring radon prevention actions when designing new buildings. Fortunately, with regard to indoor radon, the present data indicated no need for special restrictions. Average indoor radon values ranging from 1 to $100 \mathrm{~Bq} / \mathrm{m}^{3}$ were reported in some European countries ${ }^{[25]}$.

For the general public living permanently in Jeddah City, they will receive an annual effective dose estimated at $0.264 \mathrm{mSv}$ due to outdoor and indoor radon. An extra dose of $0.016 \mathrm{mSv} / \mathrm{y}$ added to individuals working in the KAU new buildings due to granite countertops results in a total dose of 0.280 $\mathrm{mSv} / \mathrm{y}$. This means that the contribution of radon to the annual global average dose rate $(2.4 \mathrm{mSv})$ is about $11.8 \%$. Extra dose means the dose due to excess radon emanating from granite slabs, which is the difference in average indoor radon concentration between the old and new buildings.

The risk of lung cancer mortality for the public, posed by lifetime exposure based on the average radon concentration, is estimated at $102.9 \times 10^{-5}$. It is estimated at $109.5 \times 10^{-5}$ for a KAU employee due to extra dose from the granite countertops. 
These values mean that for every 972 individuals living permanently in Jeddah city one person may develop a case of lung cancer due to radon; and for the occupants of KAU's new building, one lung cancer case may occur out of every 913 individuals. However, the contribution to the annual dose due to radon exposure from the countertops is very low owing to the continuous indoor air change.

\section{Conclusion}

Based on the obtained data the following conclusions can be drawn:

A slight increase in the average indoor radon concentration of the new buildings compared to that of the old buildings is due to the use of granite countertops, but still lower than the global average. The modest nature of the increase is attributed to the continuous air change inside the buildings.

The average outdoor radon level was less than the global average, may be due to the sea breeze with low radon content diluting the general air concentration of the cities located along seacoasts, like Jeddah city.

The minor difference between the average indoor and outdoor radon concentrations is attributed to the indoor air change.

Despite the slight increase in indoor radon concentration within the new buildings, the obtained data make it possible to declare that generally the radon concentration does not present significant radiological hazards for the occupants of the new buildings.

\section{Acknowledgments}

This work is financially supported by King Abdulaziz City for Science and Technology, the General Administration for research grants (Grant No. AT 36/77).

\section{Conflict of Interest}

The authors have no conflict of interest.

\section{Disclosure}

None of the authors received any type of commercial support either in forms of compensation or financial for this study. They have no financial interest in any of the products or devices, or drugs mentioned in this article.

\section{Ethical Approval}

Obtained.

\section{References}

[1] Chen J, Rahman NM, Abu Atiya IA. Radon exhalation from building materials for decorative use. J Environ Radioact 2010; 101(4): 317-322.

[2] Myatt TA, Allen JG, Minegishi T, McCarth WB, Stewart $J H$, Macintosh DL, McCarthy JF. Assessing exposure to granite countertops--Part 1: Radiation. J Expo Sci Environ Epidemiol 2010; 20(3): 273-280.

[3] Salas HT, Nalini HA, Jr, Mendes JC. Radioactivity dosage evaluation of Brazilian ornamental granitic rocks based on chemical data, with mineralogical and lithological characterization. Environ Geol 2006; 49(4): 520-526.

[4] Llope WJ. Activity concentration and dose rates from decorative granite countertops. J Environ Radioact 2011; 102(6): 620-629.

[5] Al Saleh FS, Al Berzan B. Measurements of natural radioactivity in some kinds of marble and granite used in Riyadh region. J Nucl Radiat Phys 2007; 2(1): 25-36.

[6] Allen JG, Minegishi T, Myatt TA, Stewart JH, McCarthy JF, Macintosh DL. Assessing exposure to granite countertops-Part 2: Radon. J Expo Sci Environ Epidemiol 2010; 20(3): 263-272.

[7] [No authors listed]. Mitigation Standards 1993. U.S. Environmental Protection Agency. Washington DC.

[8] [No authors listed]. Sources and effects of ionizing radiation. United Nations Scientific Committee on the Effects of Atomic Radiation. UNSCEAR 2000 Report to General Assembly with Scientific Annexes. United Nations; New York. 200.

[9] [No authors listed]. A Citizen's Guide to Radon. The Guide to Protecting Yourself and Your Family from Radon. U.S. Environmental Protection Agency, Indoor Environments Division. 2007. 1-15.

[10] Bernhardt D, Gerhart A, Kincaid L. Implications of granite countertop construction and uses. 54 $4^{\text {th }}$ Annual Meeting of the Progress Health Physics Society, July 13, 2009, Minneapolis, MN.

[11] International Commission on Radiological Protection (ICRP). Summary of the recommendations (Draft) 2007. Stockholm.

[12] Committee of Health Risks of Exposure to Radon (BEIR VI). Health effects of exposure to Radon: BEIR VI. National Research Council, Washington DC; National Acad P, 1999. 1-516.

[13] Khan AJ. A study of radon levels in Indian dwellings, influencing factors and lung cancer risks. Radiat Meas 2000; 32(2): 87-92. 
[14] Singh S, Kumar A, Singh B. Radon level in dwellings and its correlation with uranium and radium content in some areas of Himachal Pradesh, India. Environ Intern 2002; 28(1-2): 97-101.

[15] TANNER AB. Radon migration in the ground: a review. In: Natural Radiation Environment. Adams JAS, Lowder WM, eds. Chicago: Uni Chicago P, 1964. 161-190.

[16] Veiga LHS, Koifman S, Melo VP, Sachet I, Amaral ECS. Preliminary indoor radon risk assessment at the Poços de Caldas Plateau, MG-Brazil. J Environ Radioact 2003; 70(3): 161-176.

[17] [No authors listed]. Sources and effects of ionizing radiation. United Nations Scientific Committee on the Effects of Atomic Radiation. UNSCEAR 2000 Report to General Assembly with Scientific Annexes. Vol 1, Sources. United Nations; New York. 1993

[18] [No authors listed]. Radon Reference Manual. U.S. Environmental Protection Agency, Washington, DC: Office of Radiation Programs; EPA 520/1-87-20; 1987.

[19] Dung BD, Giap TV, Kovacs T, Cuong LD, Quyet NH. Indoor radon concentration measurements at the locations of the first nuclear power plants of Vietnam. Rom J Phys 2013; 58 Suppl: S108-S114.

[20] Sarrou I, Pashalidis I. Radon levels in Cyprus. J Environ Radioact 2003; 68(3): $269-277$.

[21] El-Gamal A, Hosny G. Assessment of lung cancer risk due to exposure to radon from coastal sediments. East Mediterr Health J 2008; 14(6): 1257-1269.

[22] Kinsara AA, Shabana el-SI, Abulfaraj WH, Qutub MM. Distribution of ${ }^{222} \mathrm{Rn}$ concentration in an inhabited area adjacent to the Aja granitic heights of Hail Province, Saudi Arabia. Health Phys 2015; 108(1): 59-66.

[23] Skeppström K, Olofsson B. Uranium and radon in groundwater. An overview of the problem. EurWater 2007; 17/18: 51-62.

[24] Leghrouz AA, Abu Samreh MM, Shehadeh AK. Measurement of indoor radon concentration levels in dwellings in Bethlehem, Palestine. Health Phys 2013; 104(2): 163-167.

[25] [No authors listed]. Sources to effects assessment for radon in homes and workplaces. United Nations Scientific Committee on the Effects of Atomic Radiation. UNSCEAR 2009 Report. United Nations; New York. 2009. 


\title{
تأثير الاستخدام المفرط للجرانيت في تكسية المباني الفاخرة على زيادة انبعاث غاز الرادون داخلها وتقدير المخاطر المحتملة على السكان
}

\author{
محمد سامي طيب' وعبدالرحيم عبدالرحمن كنساره

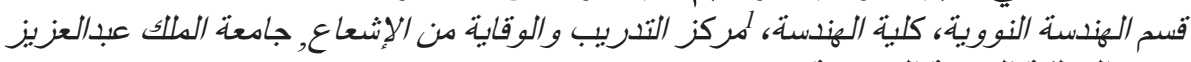 \\ جدة ـ المدلكة العربية السعودية النية
}

العستخلص. لقد تم قياس تركيز غاز الر ادون المشع داخل المباني الجديدة بجامعة الملك عبد العزيز لار اسة تأثير الاستخدام

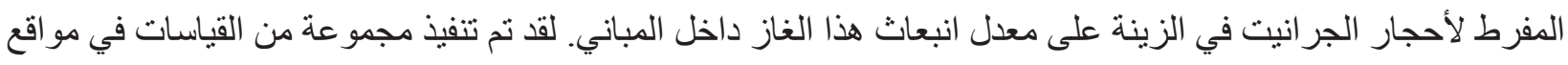

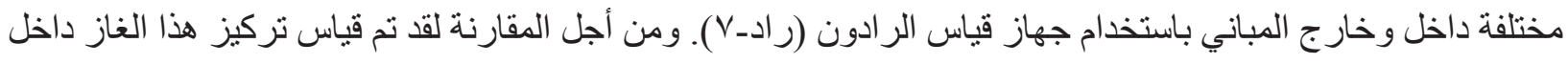

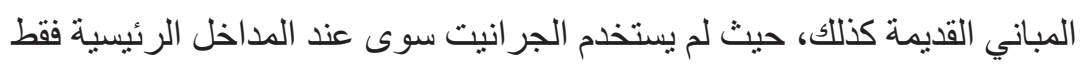

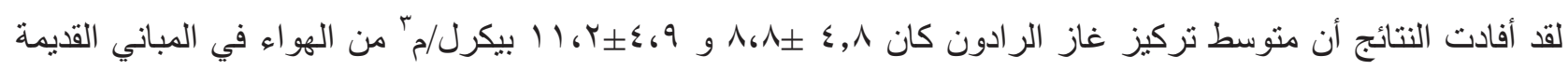

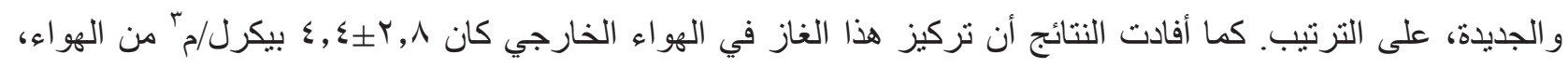

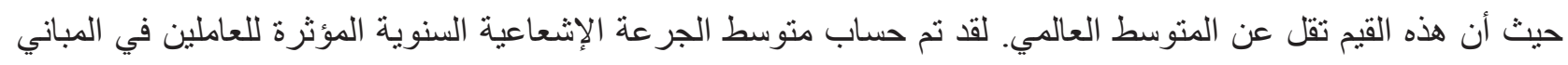

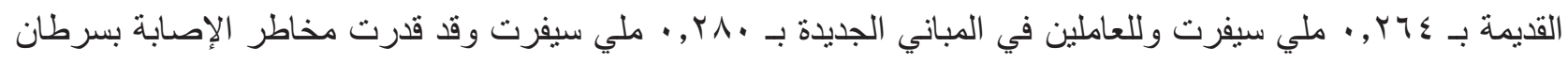

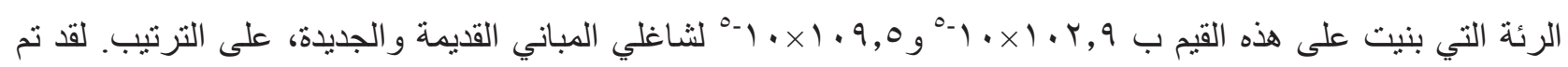
مناقثة هذه النتائج بالتفصيل في هذا البحث. 